\title{
Color-copigmentation study by tristimulus colorimetry (CIELAB) in red wines obtained from Tempranillo and Graciano varieties
}

\author{
Matilde García-Marino a , María Luisa Escudero-Gilete ${ }^{\text {b }}$, Francisco José Heredia b \\ María Teresa Escribano-Bailón a,*, Julián Carlos Rivas-Gonzalo ${ }^{\text {a }}$

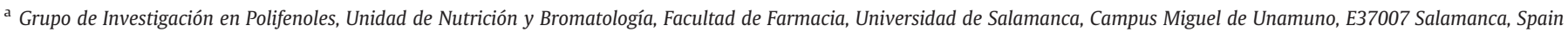 \\ ${ }^{\mathrm{b}}$ Food Color and Quality Laboratory, Deparment of Nutrition and Food Science, Facultad de Farmacia, Universidad de Sevilla, E41012, Sevilla, Spain
}

\section{A R T I C L E I N F O}

\section{Article history:}

Received 24 September 2012

Accepted 28 November 2012

Available online 13 December 2012

\section{Keywords:}

Copigmentation

Color

CIELAB

Co-winemaking

Polyphenols

\begin{abstract}
A B S T R A C T
A study of the changes of copigmentation phenomenon in wines elaborated from different varieties has been undertaken. Colorimetric measurement of Tempranillo $(\mathrm{T})$ and Graciano $(\mathrm{G})$ monovarietal wines, and two 80:20 blend wines: $\mathrm{M}$, (grape blending $\mathrm{T}$ and $\mathrm{G}$, co-maceration) and $\mathrm{W}$ (wine blending $\mathrm{T}$ and $\mathrm{G}$, co-vinification) was performed by spectrophotometry. Significant differences $(\mathrm{p}<0.05)$ were found among the color of the wines. The Graciano cv. afforded somewhat darker and more colorful wines than the other wines. The color difference values, $\Delta \mathrm{E}^{*}{ }_{\mathrm{ab}}$ suggested that co-vinification $(\mathrm{W})$ led to wines being more similar to $\mathrm{T}$ than the co-maceration $(\mathrm{M})$. The $\Delta \mathrm{E}^{*}{ }_{\mathrm{ab}[\mathrm{w}-\mathrm{c}]}$ between untreated wines - whole wines, $\mathrm{w}$ - and the wines diluted to eliminate copigmentation - corrected wines, c - was 14.2 CIELAB units in the initial stages of winemaking and 6.7 in the final stages. $\mathrm{M}$ had a greater proportion of color due to copigmentation than the monovarietal wines. Evaluation of this parameter confirms the importance of copigmentation process into wine color during the early stages of the vinification. Also, through the full spectrum, quantitative data obtained allow a visual interpretation of the changes involved. In addition, with the aging in bottle, M wines had more stable color and more different color than $\mathrm{W}$ wines.
\end{abstract}

(c) 2012 Elsevier Ltd. All rights reserved.

\section{Introduction}

The color of red wine is one of its most important quality parameters, and determines sensory evaluation to a significant extent. Generally, it is the first characteristic perceived, and therefore plays a key role in the decision-making process of the consumer, who usually tends to prefer wines with a deep color and hue.

Phenolic compounds, which are responsible for the color of wines, are transferred from the skin and seeds of grapes and diffuse into the must and wine during the maceration stage. The bright red color of young wines is mainly due to free anthocyanins, self-association, and the copigmentation of anthocyanins with other phenols present in these wines such as flavanols, flavonols and hydroxycinnamic acids (Cavalcanti, Santos, \& Meireles, 2011).

Copigmentation complexes adopt a sandwich configuration that protects the flavylium chromophore from nucleophilic attack by water, thus reducing the formation of colorless hemiketal and chalcone forms. The final result is that anthocyanin solutions show a more intense color than would be expected according to the $\mathrm{pH}$ value of the medium (Cavalcanti et al., 2011; González-Manzano, Santos-Buelga, Dueñas-Patón, Rivas-Gonzalo, \& Escribano, 2008). It appears that color extraction and retention in wine is strongly influenced by the levels of

\footnotetext{
* Corresponding author. Tel.: + 349232945 37; fax: + 34923294515. E-mail address: escriban@usal.es (M.T. Escribano-Bailón).
}

cofactors in it. Not all varieties of grapes are rich in cofactors, and neither do they all have the same quantities of anthocyanins and polyphenols. Accordingly, co-maceration of different grape varieties could favor an increase in the content of anthocyanins (García-Marino, Santos-Buelga, Rivas-Gonzalo, \& Escribano-Bailón, 2009) and could contribute to an increase in the copigmentation process (MorenoArribas \& Polo, 2008). Likewise, blends from different wines afford wines with a more balanced anthocyanin/flavanol ratio (Monagas, Bartolomé, \& Gómez-Cordovés, 2006).

The Vitis vinifera L. cv. Tempranillo is a very suitable red grape variety for the elaboration of wines destined for aging. The musts obtained from Tempranillo have an intense color, which represents a good base wine for blending. On the other hand, V. vinifera L. cv. Graciano is also a red grape variety traditionally used to improve the characteristics of Tempranillo, affording a long shelf-life, and higher color intensity and aroma to the blend. Studies performed previously have also unveiled differences between varieties as regards their composition. Thus, in the case of anthocyanins, the skins of grapes from the Graciano variety have a higher content of peonidin in comparison with malvidin than Tempranillo grapes. In contrast, Tempranillo grapes have higher contents of delphinidin and petunidin in comparison with malvidin than Graciano grapes (Escudero-Gilete, González-Miret, \& Heredia, 2010). These differences between the varieties are also seen in their flavanols, since it has been reported that the absolute content of these flavan3-ols is higher in Graciano grapes than in the Tempranillo variety 
(Núñez, Gómez-Cordovés, Bartolomé, Hong, \& Alysone-Mitchell, 2006). According to Monagas, Gómez-Cordovés, Bartolomé, Laureano, and Ricardo Da Silva (2003) the seeds of grapes of the Graciano variety have higher concentrations of flavanols than those of Tempranillo grapes. Likewise, the seeds the Graciano variety grapes have higher contents of monomers than those of the Tempranillo variety (Núñez et al., 2006); the concentration of the monomer epicatechin is higher or similar to that of catechin (Monagas et al., 2003).

Thus, blends between these varieties by co-maceration or by the blending of wines, "coupage", could lead to a final product with a greater phenolic material, allowing the elaboration of wines with more stable color over time. Colorimetric study of the original wines, as well as their blends, may lead to a better knowledge of the influence of the particular grape variety on the color of the wine. According to Boulton (2001), the presence of copigments in the grape exerts a strong influence on the color density of young red wine and on the greater or lesser stability of the color during the aging of the wine (Darías-Martín, Carrillo, Díaz \& Boulton, 2001; Darías-Martín et al., 2002; Gonzalez-Manzano, Dueñas, Rivas-Gonzalo, Escribano-Bailón, \& Santos-Buelga, 2009; Schwarz, Picazo-Bacete, Winterhanlter, \& Hermosín-Gutiérrez, 2005).

Boulton (1996) developed a spectrophotometric method (by measurement of the visible $\lambda_{\max }$ ) to evaluate the magnitude of copigmentation in red wines, improving the method proposed by Somers and Evans (1977). From the colorimetric point of view, an adequate description of the color variations of wines caused by copigmentation requires the consideration that the spectral variations observed would affect the entire spectral curve, and not only its visible $\lambda_{\max }$ (Fig. 1). In this respect, Gómez-Míguez, GonzálezManzano, Escribano-Bailón, Heredia, and Santos-Buelga (2006) carried out preliminary tests using tristimulus colorimetry to explain the copigmentation phenomenon. Tristimulus colorimetry, through calculation of the $\Delta \mathrm{E}^{*}$ ab parameter (difference in color), among others, allows the interpretation of copigmentation at the visual level.

Research into the industrial evaluation of color differences has undergone significant progress in recent years (Liu, Chen, Hao, Zheng, \& Jia, 2012; Melgosa et al., 2009; Oleari, Melgosa, \& Huertas, 2011; Rodríguez-Pulido et al., 2012; Zheng, Zhou, Qi, \& Zhang, 2012). Nonetheless, there is very little previous information about the application of the color differences into the study of copigmentation. Thus, the aim of the present work was to apply this methology in the study of the copigmentation phenomenon of red wines elaborated with different varieties (Graciano cv. and Tempranillo cv.) during winemaking, offering a colorimetric interpretation of the above mentioned effect.

\section{Materials and methods}

\subsection{Winemaking and samples}

The wines were elaborated by Bodegas RODA (Haro, La Rioja, Spain) corresponding to two consecutive harvests. The $T$ and $G$ wines were made from $V$. vinifera $\mathrm{cv}$. Tempranillo and Graciano fresh grapes, respectively. $M$ wines were elaborated by blending of Tempranillo and Graciano grapes (80:20) - comaceration, and W wines from a blending of $\mathrm{T}$ and $\mathrm{G}$ wines $(80: 20 \mathrm{v} / \mathrm{v})$ after malolactic fermentation - co-vinification or coupage. The enological parameters determined in wines during the vinification process of these grape varieties are shown in Table 1 . Winemaking was performed as follows. Grapes were crushed and destemmed and the mass was put into $1200 \mathrm{~L}$ stainless steel vats. After pre-fermentative maceration stage (2-4 days at $14{ }^{\circ} \mathrm{C}$ ) the alcoholic fermentation process last 7-12 days. After post-fermentative maceration (5-7 days), wines were transferred to $225 \mathrm{~L}$ French oak barrels where the malolactic fermentation occurred (approximately 30 days at $21^{\circ} \mathrm{C}$ ). The aging process took approximately 14 months $\left(9-12{ }^{\circ} \mathrm{C}\right)$. Finally, the wines obtained were clarified, bottled and stored at $16-18{ }^{\circ} \mathrm{C}$ (12 months).
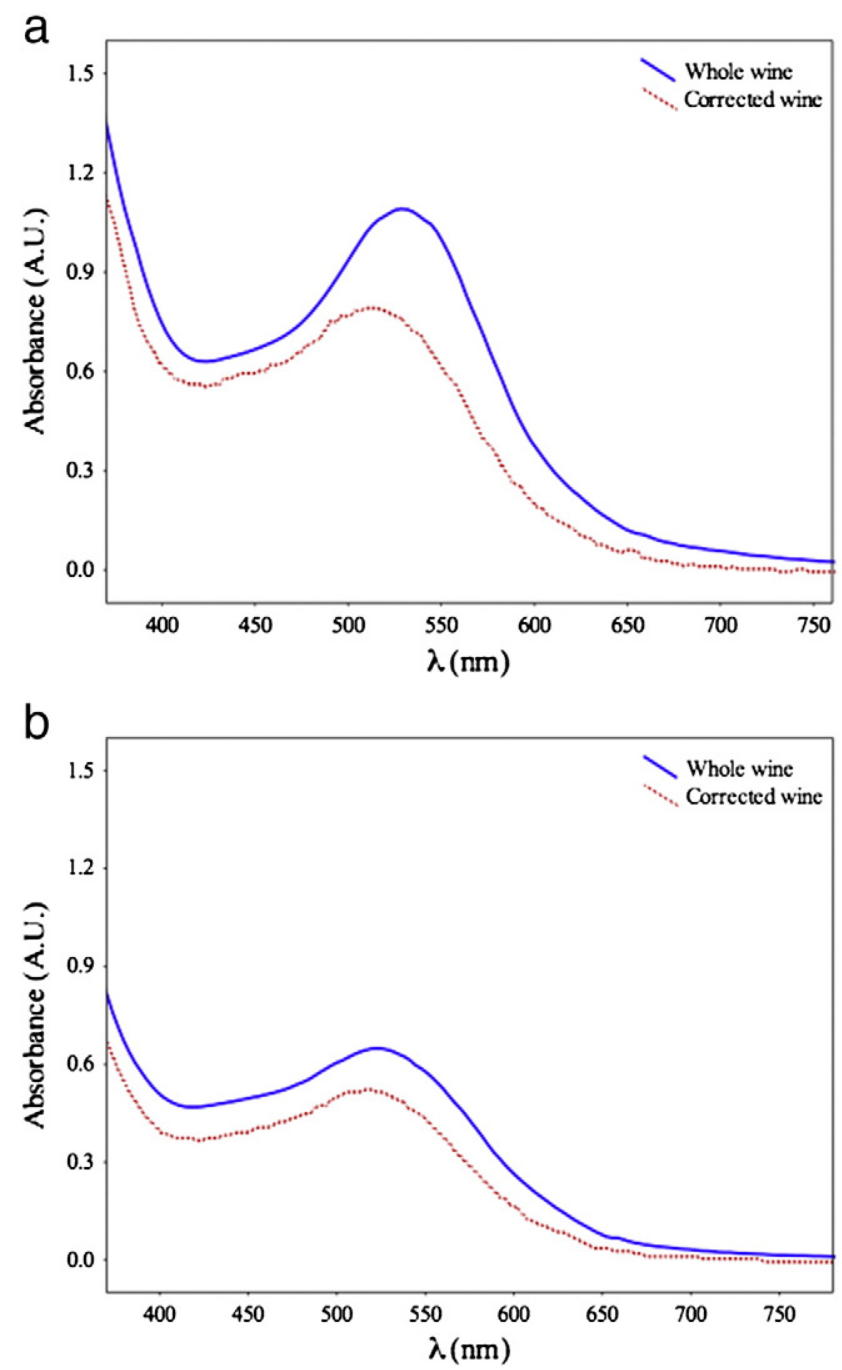

Fig 1. Whole and corrected wine spectra. (a) The color differences are not similar along the entire spectral curve; (b) spectra with similar color differences along the entire spectral curve.

Samples were collected periodically during the winemaking and aging process and are summarized in Table 2.

The number of samples was 88 . These samples corresponded to 12 steps for the T, G and M wines and 8 steps for the $\mathrm{W}$ wine. All wine samples were taken in triplicate and analyzed separately.

\subsection{Enological parameters}

Sugar content, $\mathrm{pH}$, and titratable acidity in grape samples were determined using the International Organization of Vine and Wine (OIV, 2009). Other oenological parameters (acetic acid and malic acid) were quantified by automated enzymatic determination. Titratable acidity, $\mathrm{pH}$ and free $\mathrm{SO}_{2}$ in wine samples were determined following the methods of analysis of the International Organization of Vine and Wine (OIV, 2009) and volatile acidity was determined according to the method proposed by García-Barceló (1980). Color intensity was estimated using the method described by Glories (1984), anthocyanins were determined by the Riberéau-Gayon and Stonestreet method (Ribéreau-Gayon \& Stonestreet, 1965), and total polyphenolic index was determined by UV absorption at $280 \mathrm{~nm}$ (Glories, 1984). 
Table 1

Enological parameters determined in wines during winemaking process, for T, G and M wines.

\begin{tabular}{|c|c|c|c|c|c|c|}
\hline Wine & $\mathrm{T}$ & & G & & M & \\
\hline Vintage & 2005 & 2006 & 2005 & 2006 & 2005 & 2006 \\
\hline Vineyard date & 05/10/2005 & 21/09/2006 & 05/10/2005 & $02 / 10 / 2006$ & 05/10/2005 & $21 / 09 / 2006$ \\
\hline Vineyard yield (kg/Ha) & 6506 & 3917 & 7045 & 3854 & & \\
\hline $\mathrm{pH}$ & 3.8 & 3.7 & 3.5 & 3.4 & 3.4 & 3.5 \\
\hline Sugar content ( ${ }^{\circ}$ Baume $)$ & 13.6 & 13.6 & 14.1 & 13.6 & 13.2 & 13.0 \\
\hline Titratable acidity ( $\mathrm{g} / \mathrm{L}$ sulfuric acid) & 3.2 & 3.5 & 3.1 & 5.2 & 3.1 & 3.8 \\
\hline Malic acid (g/L) & 2.2 & 2.7 & 1.6 & 2.8 & 2.1 & 2.6 \\
\hline Tartaric acid (g/L) & 4.0 & 6.3 & 4.7 & 6.2 & 4.7 & 6.8 \\
\hline \multicolumn{7}{|l|}{ End of alcoholic fermentation } \\
\hline Time (days) & 10 & 7 & 12 & 12 & 7 & 7 \\
\hline $\mathrm{pH}$ & 4.0 & 4.1 & 3.5 & 3.6 & 3.8 & 4.0 \\
\hline Colour intensity (AU) & 25.4 & 17.8 & 37.2 & 31.8 & 28.4 & 22.5 \\
\hline Titratable acidity (g/L sulfuric acid) & 3.9 & 3.8 & 4.9 & 4.7 & 4.2 & 4.2 \\
\hline Volatile acidity (g/L acetic acid) & 0.5 & 0.3 & 0.6 & 0.3 & 0.4 & 0.3 \\
\hline Total polyphenol index $\left(\mathrm{Abs}^{280}\right)(\mathrm{AU})$ & 84.5 & 81.4 & 81.8 & 83.1 & 84.8 & 86.3 \\
\hline Total anthocyanins (mg/L) & 1007.5 & 832.3 & 1122.4 & 1119.7 & 1049.0 & 928.6 \\
\hline \multicolumn{7}{|l|}{ End of malolactic fermentation } \\
\hline $\mathrm{pH}$ & 4.0 & 4.2 & 3.7 & 3.7 & 4.0 & 3.8 \\
\hline Colour intensity (AU) & 18.9 & 13.9 & 25.5 & 23.0 & 18.3 & 17.0 \\
\hline Titratable acidity (g/L sulfuric acid) & 3.0 & 2.8 & 3.4 & 3.8 & 2.9 & 3.0 \\
\hline Volatile acidity (g/L acetic acid) & 0.6 & 0.5 & 0.6 & 0.6 & 0.6 & 0.4 \\
\hline Total polyphenol index $\left(\mathrm{Abs}^{280}\right)(\mathrm{AU})$ & 82.8 & 80.0 & 79.5 & 81.0 & 82.7 & 84.0 \\
\hline Total anthocyanins (mg/L) & 657.2 & 698.5 & 862.0 & 789.8 & 743.3 & 721.0 \\
\hline Free $\mathrm{SO}_{2}(\mathrm{mg} / \mathrm{L})$ & 15.0 & 14.0 & 18.0 & - & 15.0 & 13.0 \\
\hline
\end{tabular}

\subsection{Chemical analyses}

\subsubsection{Wine sample handling conditions}

For the analysis of anthocyanins and flavonols, $1 \mathrm{~mL}$ of wine sample was diluted $(1: 1 \mathrm{v} / \mathrm{v})$ with $0.1 \mathrm{Eq}-\mathrm{g} / \mathrm{L} \mathrm{HCl}$. Then, the samples were filtered through $0.45 \mu \mathrm{m}$ Millex® syringe-driven filter units and injected directly into the chromatographic system.

The analysis of flavanols and phenolic acids was carried out according to García-Marino, Ibañez, Rivas-Gonzalo, and García-Moreno (2006). With a view to eliminating the red pigments, $2 \mathrm{~mL}$ of each wine sample was eluted through Oasis ${ }^{\circledR}$ MCX 3 cc (60 mg) cartridges (Waters Corporation Milford, Massachussets, USA) previously conditioned with $2 \mathrm{~mL}$ of methanol and $2 \mathrm{~mL}$ of water. After washing with $4 \mathrm{~mL}$ of ultrapure water, the flavan-3-ols and the phenolic acids were

Table 2

Sampling of T, G, M and $\mathrm{W}$ wines during the winemaking and aging in oak barrel and bottle.

\begin{tabular}{|c|c|c|}
\hline Step & Sampling & Days \\
\hline \multicolumn{2}{|c|}{ Stage 1: alcoholic fermentation } & \\
\hline 01 & End of the alcoholic fermentation & 16 \\
\hline 02 & End of post-fermentative maceration & 20 \\
\hline \multicolumn{2}{|c|}{ Stage 2: malolactic fermentation } & \\
\hline 03 & Beginning of malolactic fermentation & 22 \\
\hline 04 & Mid of malolactic fermentation & 29 \\
\hline $05^{\mathrm{a}}$ & End of malolactic fermentation & 39 \\
\hline \multicolumn{2}{|c|}{ Stage 3: aging in oak barrels } & C. \\
\hline 06 & 1st racking (after 3 months in French oak barrels) & 128 \\
\hline 07 & 2nd racking (after 6 months in French oak barrels) & 219 \\
\hline 08 & 3rd racking (after 12 months in French oak barrels) & 413 \\
\hline 09 & Clarification and bottling (after 14 months in French oak barrels) & 460 \\
\hline \multicolumn{2}{|r|}{ Stage 4: aging in bottle } & \\
\hline 10 & After 5 months of aging in bottle & 602 \\
\hline 11 & After 9 months of aging in bottle & 736 \\
\hline 12 & After 12 months of aging in bottle & 827 \\
\hline
\end{tabular}

a In the case of $\mathrm{W}$ wine, the samples were collected as from step 5 . eluted with $8 \mathrm{~mL}$ of methanol. A small volume of water was added to the eluate, and this was concentrated under a vacuum at a temperature lower than $30^{\circ} \mathrm{C}$ until the complete elimination of methanol was achieved. The volume of the aqueous residue was adjusted to $0.5 \mathrm{~mL}$ with ultrapure water (MilliQ), filtered $(0.45 \mathrm{~mm})$, and analysed by HPLC-DAD-MS.

\subsubsection{HPLC-DAD-MS analysis}

HPLC-DAD analyses were performed with a Hewlett-Packard 1100 series liquid chromatograph. The LC system was connected to the probe of the mass spectrometer via the UV cell outlet. Mass analyses were performed using a Finnigan ${ }^{\mathrm{TM}}$ LCQ ion-trap detector (Thermoquest, San Jose, CA, USA) equipped with an API source, using an electrospray ionization (ESI) interface. The HPLC-DAD-MS analysis conditions used to carry out the analyses of red pigments and flavonols were in accordance with García-Marino, Hernández-Hierro, Rivas-Gonzalo, and Escribano-Bailón (2010), selecting an additional wavelength at $360 \mathrm{~nm}$ to achieve the analysis of flavonols. Analyses of flavan-3-ols and phenolic acids were carried out as described by García-Marino et al. (2009), selecting an additional wavelength at $330 \mathrm{~nm}$ to achieve the analysis of phenolic acids.

\subsubsection{Quantification}

For the quantitative analyses, calibration curves were obtained using standards of anthocyanins (delphinidin, cyanidin, petunidin, peonidin and malvidin 3-0-glucosides), flavonols (myricetin, quercetin and kaempferol), flavanols (catechin, gallocatechin, epicatechin gallate, dimer B2 and trimer epicatechin-4,8-epicatechin-4,8-catechin) and phenolic acids (3,4-dyhydroxybenzoic acid and 4-hydroxycinnamic acid). Anthocyanins were purchased from Polyphenols Labs. (Sandnes, Norway). Myricetin, kaempferol, (+)-gallocatechin and (-)-epicatechin gallate were purchased from Extrasynthèse (Genay, France). Quercetin, (+)-catechin, 3,4-dyhydroxybenzoic acid and 4-hydroxycinnamic acid were purchased from Sigma (Steinheim, Germany). Procyanidin dimer and trimer were obtained at our laboratory by Escribano-Bailón, Gutiérrez-Fernández, Rivas-Gonzalo, and Santos-Buelga (1992).

Owing to the considerable diversity of phenolic compounds identified, many of them did not have standards available. For this reason, the different pigments identified (46 compounds) were quantified as the 
corresponding monoglucoside. In the case of the flavanols: catechins, dimers of procyanidins, oliogomer procyanidins, prodelphinidins and galloylated derivatives, were quantified using catechin, B2 dimer, EEC trimer, gallocatechin and epicatechin 3-0-gallate, as external standards respectively.

The hydroxybenzoic phenolic acids were quantified as protocatechic acid, while the hydroxycinnamic acids identified were quantified as p-coumaric acid. Finally, the flavonols were quantified as their aglycon, with the exception of isorhamnetin, which was quantified as quercetin aglycon.

The total content of the different groups of phenolic compounds studied was calculated from the sum of the individual concentrations obtained for each individual compound, expressed in $\mathrm{mg} / \mathrm{L}$ of wine.

\subsection{CIELAB color space}

The wine samples were filtered through Millipore-AP20 filters (Millipore Corporation, Bedford, MA, USA) prior to the spectrophotometric analysis. The colorimetric implications of the copigmentation phenomenon as regards the total color of wine samples were evaluated by tristimulus colorimetry from the entire visible spectrum $(380-770 \mathrm{~nm}$ ). Previously, all the wine samples were adjusted to $\mathrm{pH} 3.6$ with $\mathrm{HCl}$ $0.5 \mathrm{Eq}-\mathrm{g} / \mathrm{L}$ or $\mathrm{NaOH} 0.5 \mathrm{Eq}-\mathrm{g} / \mathrm{L}$ (Panreac®, Barcelona, España), and then acetaldehyde was added. The wine color including the copigmentation effect (untreated wines or whole wines) was obtained from the absorbance spectrum of the wines. The wine color without the copigmentation effect (wines diluted to eliminate copigmentation or corrected wines) was reconstituted from the absorbance spectrum of the wine sample after diluting 20 -fold with a synthetic wine solution $(5 \mathrm{~g} / \mathrm{L}$ of tartaric acid, dissolved in $12 \%$ ethanol solution $(\mathrm{v} / \mathrm{v})$ at $\mathrm{pH} 3.6$ and an ionic strength of $0.2 \mathrm{~mol} / \mathrm{L}$ ) and multiplying by the dilution factor. That dilution led to the dissociation of the complex responsible for the copigmentation. Spectrophotometric measurements of the original and diluted wines were performed. The whole visible spectrum $(380-770 \mathrm{~nm})$ was recorded at constant intervals $(\Delta \lambda=2 \mathrm{~nm}$ ) with a Hewlett-Packard HP8452 UV-vis spectrophotometer (Palo Alto, CA), using 2-mm path length quartz cells and a synthetic wine solution $(\mathrm{pH} 3.6 ; 0.2 \mathrm{~mol} / \mathrm{L})$ as a reference. The CIELAB parameters $\left(\mathrm{L}^{*}, \mathrm{a}^{*}, \mathrm{~b}^{*}, \mathrm{C}^{*}{ }_{\mathrm{ab}}\right.$, and $\left.\mathrm{h}_{\mathrm{ab}}\right)$ were determined using the original CromaLab ${ }^{\circledR}$ software (Heredia, Álvarez, González-Miret, \& Ramirez, 2004), following the recommendations of the Commission Internationale de L'Eclariage (CIE, 2004): the $10^{\circ}$ Standard Observer and the Standard Illuminant D65.

Color differences $\left(\Delta \mathrm{E}_{\mathrm{ab}}^{*}\right.$ ) between two color points in the CIELAB space are calculated as the Euclidean distance between their locations in the three-dimensional space defined by $\mathrm{L}^{*}, \mathrm{a}^{*}$, and $\mathrm{b}^{*}$. Thus, mathematically, they are calculated by applying the formula:

$\Delta E_{a b}^{*}=\sqrt{(\Delta L *)^{2}+(\Delta a *)^{2}+(\Delta b *)^{2}}$.

\subsection{Statistical analyses}

For sample comparison, the data are presented as means \pm standard deviation (SD) of analyses performed in triplicate. Significant differences $(\mathrm{p}<0.05$ and $\mathrm{p}<0.01)$ among the wines and for each variable were assessed by analysis of variance (ANOVA) and Tukey's honestly significant differences test.

A 2 (whole and corrected wines) $\times 5$ (colorimetric variables) repeated-measures ANOVA was carried out with cases (wines) as a random factor, in order to establish differences between the wines with copigmentation (whole wines) and wines without copigmentation (corrected wines) and the five colorimetric variables (Norman \& Streiner, 1996).

Data analyses were performed using the Statistica ${ }^{\circledR}$ V 8.0 software (StatSoft, 2007).

\section{Results and discussion}

\subsection{Chemical composition of wines}

A total of 46 anthocyanins and anthocyanin-derived pigments were identified in wine samples between non-acylated anthocyanins [common anthocyanin monoglucosides and diglucosides: monoglucosides of cyanidin (Cy), delphinidin (Dp), petunidin (Pt), peonidin (Pn), malvidin (Mv)], acylated anthocyanins, pyranoanthocyanins, direct flavanolanthocyanin condensation products and acetaldehyde mediated flavanol-anthocyanin condensation products. In regards to flavan-3-ols, a total of 20 compounds were identified comprising prodelphinidins, procyanidins and (epi)catechin monomers. We also identified 12 flavonols, which were glycosides and aglycones of myricetin, quercetin, kaempferol and isorhamnetin. Finally, 12 phenolic acids were identified (4 hydroxybenzoic acids and 8 hydroxycinnamic acids).

In order to better explain the changes occurred in the wine samples during the winemaking process, regardless of vintage, samples from two vintages were considered together.

Table 3 shows the mean concentration of the different polyphenolic compounds during the different winemaking stages of the T, G, M and $\mathrm{W}$ wines (steps $1-2$, alcoholic fermentation (stage 1 ); steps 3-5, malolactic fermentation (stage 2); steps 6-9, aging in oak barrels (stage 3); steps 10-12, aging in bottle (stage 4)). Statistically significant differences were seen in the quantified total pigment contents between the $\mathrm{T}$ and the $\mathrm{G}$ and $\mathrm{M}$ wines in the initial winemaking stages (steps 1-2 and 3-5) but not in the final steps (10-12). In the early stages of winemaking, the quantified total pigment content in the $\mathrm{M}$ wine was significantly higher than the expected content, taking into account that only $20 \%$ of the Graciano grape variety was used in the vinification of the M wine (García-Marino et al., 2010). This could be due to the fact that the process of grape co-maceration (Tempranillo + Graciano) allows the collection of $\mathrm{M}$ wines with more protected anthocyanins than wines elaborated only with the Tempranillo grape variety, possibly due to a greater effect of the copigmentation phenomenon. In final stages (steps 10-12), the T wine showed the lowest quantified total pigment content $(556.7 \mathrm{mg} / \mathrm{L})$. Regarding the final content of quantified total pigments ( similar quantified total pigment concentration that the blend of wines W (537 mg/L and $540.4 \mathrm{mg} / \mathrm{L}$ respectively); in turn, the quantified total pigment content of the $\mathrm{M}$ and $\mathrm{W}$ wines was intermediate with respect to that seen for the monovarietal G $(554.0 \mathrm{mg} / \mathrm{L})$ and $\mathrm{T}(508.0 \mathrm{mg} / \mathrm{L})$ wines.

As from the initial stage (steps 1-2), the concentration of phenolic acids in the $\mathrm{T}$ wines $(93.2 \mathrm{mg} / \mathrm{L})$ was higher than in the $\mathrm{G}$ and $\mathrm{M}$ wines (88.6 and $90.1 \mathrm{mg} / \mathrm{L}$ ). In the final stages (steps 10-12), the $\mathrm{M}$ and $\mathrm{W}$ wines (108.2 and $107.1 \mathrm{mg} / \mathrm{L}$, respectively) had intermediate concentrations between both the T and G monovarietal wines (109.3 and $102.3 \mathrm{mg} / \mathrm{L}$, respectively), although these differences were not statistically significant (Table 3 ).

In the initial stage, there were no noticeable differences in the flavonol content (red wine cofactors that are of greater importance in the copigmentation phenomenon (Brouillard, Mazza, Saad, Albrecht-Gary, \& Cheminat, 1989; Boulton, 2001) among the wines. The flavonol content decreased in all wines as the vinification process progressed to its final stages. Differences were observed in final step (step 12). Thus, Table 3 shows that the $\mathrm{M}$ wines had a significantly higher total flavonol concentration $(233.8 \mathrm{mg} / \mathrm{L})$ than the $\mathrm{T}$ and $\mathrm{G}$ wines (223.3 and $222.8 \mathrm{mg} / \mathrm{L}$, respectively), whereas with the $\mathrm{W}$ wines not showed significant differences $(225.0 \mathrm{mg} / \mathrm{L})$.

As from the initial stages (steps 1-2) the flavan-3-ol concentration of the $\mathrm{G}$ wine $(510.1 \mathrm{mg} / \mathrm{L})$ was significantly higher than the $\mathrm{T}$ wines (417.0 $\mathrm{mg} / \mathrm{L}$ ), and without showing significant differences with the $\mathrm{M}$ wines $(442.8 \mathrm{mg} / \mathrm{L}$ ) (Table 3). According to Liao, Cai, and Haslam (1992), after pigments, flavan-3-ols are the most abundant phenolic compound group in red wines. Nevertheless, compared with flavonols, 
Table 3

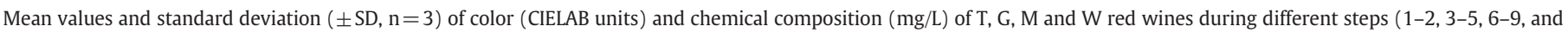
10-12) and final step (step 12)).

\begin{tabular}{|c|c|c|c|c|c|}
\hline \multirow[t]{2}{*}{ Variable } & \multirow[t]{2}{*}{ Stages (steps) } & \multicolumn{4}{|l|}{ Wine } \\
\hline & & $\overline{\mathrm{T}}$ & G & $\mathrm{M}$ & $\mathrm{W}^{1}$ \\
\hline \multirow[t]{5}{*}{$a^{*}$} & $1-2$ & $57.0 \pm 3.0^{\mathrm{a}}$ & $60.8 \pm 2.0^{\mathrm{b}}$ & $59.3 \pm 2.0^{\mathrm{a}, \mathrm{b}}$ & \\
\hline & $3-5$ & $49.8 \pm 3.9^{\mathrm{a}, \mathrm{b}}$ & $55.9 \pm 2.9^{c}$ & $52.9 \pm 3.8^{\mathrm{b}, \mathrm{c}}$ & $47.8 \pm 5.6^{\mathrm{a}}$ \\
\hline & $6-9$ & $45.5 \pm 3.5^{\mathrm{a}}$ & $49.0 \pm 3.1^{\mathrm{b}}$ & $45.6 \pm 4.2^{\mathrm{a}}$ & $45.4 \pm 3.3^{\mathrm{a}}$ \\
\hline & $10-12$ & $38.7 \pm 3.5^{\mathrm{a}}$ & $41.3 \pm 3.3^{\mathrm{a}}$ & $38.6 \pm 2.4^{\mathrm{a}}$ & $38.8 \pm 3.3^{\mathrm{a}}$ \\
\hline & Final & $37.2 \pm 3.6^{\mathrm{a}}$ & $40.5 \pm 2.0^{\mathrm{a}}$ & $37.0 \pm 2.2^{\mathrm{a}}$ & $38.3 \pm 3.0^{\mathrm{a}}$ \\
\hline \multirow[t]{5}{*}{$b^{*}$} & $1-2$ & $2.0 \pm 1.7^{\mathrm{a}}$ & $6.1 \pm 1.3^{\mathrm{b}}$ & $1.5 \pm 0.6^{\mathrm{a}}$ & \\
\hline & $3-5$ & $1.3 \pm 2.7^{\mathrm{a}}$ & $2.6 \pm 1.1^{\mathrm{a}}$ & $1.7 \pm 1.4^{\mathrm{a}}$ & $1.7 \pm 0.7^{\mathrm{a}}$ \\
\hline & $6-9$ & $3.1 \pm 0.8^{b}$ & $1.9 \pm 1.1^{\mathrm{a}}$ & $2.0 \pm 1.1^{\mathrm{a}}$ & $2.8 \pm 0.9^{b}$ \\
\hline & $10-12$ & $5.5 \pm 0.8^{\mathrm{b}}$ & $3.6 \pm 1.3^{a}$ & $4.3 \pm 1.0^{\mathrm{a}}$ & $5.5 \pm 0.9^{b}$ \\
\hline & Final & $6.0 \pm 0.5^{b}$ & $3.9 \pm 0.9^{\mathrm{a}}$ & $4.8 \pm 0.7^{\mathrm{a}, \mathrm{c}}$ & $5.7 \pm 0.5^{\mathrm{b}, \mathrm{c}}$ \\
\hline \multirow[t]{5}{*}{$\mathrm{L}^{*}$} & $1-2$ & $46.4 \pm 3.7^{\mathrm{b}}$ & $40.7 \pm 2.2^{\mathrm{a}}$ & $45.4 \pm 1.6^{\mathrm{b}}$ & \\
\hline & $3-5$ & $51.2 \pm 4.9^{\mathrm{b}}$ & $44.3 \pm 2.5^{\mathrm{a}}$ & $48.1 \pm 3.5^{\mathrm{b}}$ & $52.0 \pm 5.2^{\mathrm{b}}$ \\
\hline & $6-9$ & $54.1 \pm 3.9^{\mathrm{b}}$ & $49.7 \pm 2.3^{\mathrm{a}}$ & $54.4 \pm 3.0^{\mathrm{b}}$ & $53.8 \pm 3.6^{\mathrm{b}}$ \\
\hline & $10-12$ & $57.3 \pm 5.2^{\mathrm{a}}$ & $54.6 \pm 3.7^{\mathrm{a}}$ & $57.9 \pm 3.1^{\mathrm{a}}$ & $56.8 \pm 5.6^{\mathrm{a}}$ \\
\hline & Final & $58.3 \pm 5.4^{\mathrm{a}}$ & $55.5 \pm 3.0^{\mathrm{a}}$ & $59.2 \pm 2.8^{\mathrm{a}}$ & $57.8 \pm 4.7^{\mathrm{a}}$ \\
\hline \multirow[t]{5}{*}{$C^{*}{ }_{a b}$} & $1-2$ & $57.1 \pm 3.1^{\mathrm{a}}$ & $61.1 \pm 2.1^{\mathrm{b}}$ & $59.3 \pm 2.0^{\mathrm{a}, \mathrm{b}}$ & \\
\hline & $3-5$ & $49.9 \pm 4.0^{\mathrm{a}, \mathrm{c}}$ & $55.9 \pm 3.0^{\mathrm{b}}$ & $53.0 \pm 3.8^{\mathrm{b}, \mathrm{c}}$ & $47.8 \pm 5.6^{\mathrm{a}}$ \\
\hline & $6-9$ & $45.6 \pm 3.5^{\mathrm{a}}$ & $49.0 \pm 3.1^{\mathrm{b}}$ & $45.7 \pm 4.2^{\mathrm{a}}$ & $45.5 \pm 3.3^{\mathrm{a}}$ \\
\hline & $10-12$ & $39.1 \pm 3.4^{\mathrm{a}}$ & $41.5 \pm 3.2^{\mathrm{a}}$ & $38.9 \pm 2.3^{\mathrm{a}}$ & $39.2 \pm 3.2^{\mathrm{a}}$ \\
\hline & Final & $37.7 \pm 3.7^{\mathrm{a}}$ & $40.7 \pm 2.0^{\mathrm{a}}$ & $37.4 \pm 2.1^{\mathrm{a}}$ & $38.7 \pm 3.1^{\mathrm{a}}$ \\
\hline \multirow[t]{5}{*}{$\mathrm{h}_{\mathrm{ab}}$} & $1-2$ & $2.0 \pm 1.6^{\mathrm{a}}$ & $5.6 \pm 1.0^{\mathrm{b}}$ & $1.5 \pm 0.5^{\mathrm{a}}$ & \\
\hline & $3-5$ & $1.4 \pm 3.0^{\mathrm{a}}$ & $2.6 \pm 1.0^{\mathrm{a}}$ & $1.8 \pm 1.4^{\mathrm{a}}$ & $2.0 \pm 0.7^{\mathrm{a}}$ \\
\hline & $6-9$ & $3.9 \pm 0.9^{b}$ & $2.2 \pm 1.3^{\mathrm{a}}$ & $2.6 \pm 1.6^{\mathrm{a}}$ & $3.6 \pm 1.1^{\mathrm{b}}$ \\
\hline & $10-12$ & $8.1 \pm 1.4^{\mathrm{b}}$ & $5.1 \pm 2.2^{\mathrm{a}}$ & $6.4 \pm 1.9^{\mathrm{a}}$ & $8.1 \pm 1.6^{\mathrm{b}}$ \\
\hline & Final & $9.2 \pm 0.2^{\mathrm{c}}$ & $5.5 \pm 1.5^{\mathrm{a}}$ & $7.4 \pm 1.6^{\mathrm{b}}$ & $8.4 \pm 0.1^{\mathrm{b}, \mathrm{c}}$ \\
\hline \multirow[t]{5}{*}{ Quantified total pigments } & $1-2$ & $1306.1 \pm 57.7^{\mathrm{a}}$ & $1473.1 \pm 53.4^{\mathrm{b}}$ & $1442.5 \pm 58.9^{\mathrm{b}}$ & \\
\hline & $3-5$ & $1047.0 \pm 91.6^{\mathrm{a}}$ & $1315.1 \pm 118.3^{c}$ & $1184.0 \pm 102.7^{\mathrm{b}}$ & $1034.8 \pm 102.0^{\mathrm{a}}$ \\
\hline & $6-9$ & $794.2 \pm 118.9^{\mathrm{a}}$ & $830.0 \pm 151.0^{\mathrm{a}}$ & $809.4 \pm 131.7^{\mathrm{a}}$ & $790.6 \pm 120.3^{a}$ \\
\hline & $10-12$ & $556.7 \pm 83.1^{\mathrm{a}}$ & $602.4 \pm 58.4^{\mathrm{a}}$ & $588.3 \pm 76.1^{\mathrm{a}}$ & $591.1 \pm 99.5^{\mathrm{a}}$ \\
\hline & Final & $508.0 \pm 85.4^{\mathrm{a}}$ & $554.0 \pm 54.8^{\mathrm{a}}$ & $537.7 \pm 72.2^{\mathrm{a}}$ & $540.4 \pm 96.5^{\mathrm{a}}$ \\
\hline \multirow{5}{*}{ Total phenolic acids } & $1-2$ & $93.2 \pm 7.9^{\mathrm{a}}$ & $88.6 \pm 5.1^{\mathrm{a}}$ & $90.1 \pm 6.3^{\mathrm{a}}$ & \\
\hline & $3-5$ & $107.0 \pm 15.4^{\mathrm{a}, \mathrm{b}}$ & $99.9 \pm 11.6^{\mathrm{a}}$ & $103.2 \pm 9.2^{\mathrm{a}, \mathrm{b}}$ & $117.0 \pm 12.5^{\mathrm{b}}$ \\
\hline & $6-9$ & $115.6 \pm 18.4^{\mathrm{a}}$ & $108.9 \pm 3.8^{a}$ & $115.1 \pm 11.3^{\mathrm{a}}$ & $115.6 \pm 12.6^{\mathrm{a}}$ \\
\hline & $10-12$ & $109.3 \pm 12.4^{\mathrm{a}}$ & $102.3 \pm 2.3^{\mathrm{a}}$ & $108.2 \pm 8.7^{\mathrm{a}}$ & $107.1 \pm 9.8^{\mathrm{a}}$ \\
\hline & Final & $105.5 \pm 7.2^{\mathrm{a}}$ & $101.1 \pm 1.3^{\mathrm{a}}$ & $105.6 \pm 4.7^{\mathrm{a}}$ & $104.5 \pm 5.3^{\mathrm{a}}$ \\
\hline \multirow[t]{5}{*}{ Total flavonols } & $1-2$ & $234.9 \pm 21.0^{\mathrm{a}}$ & $247.0 \pm 25.5^{\mathrm{a}}$ & $244.2 \pm 11.1^{\mathrm{a}}$ & \\
\hline & $3-5$ & $228.2 \pm 20.4^{\mathrm{a}}$ & $239.7 \pm 21.0^{\mathrm{a}}$ & $239.5 \pm 12.6^{a}$ & $225.6 \pm 20.2^{\mathrm{a}}$ \\
\hline & $6-9$ & $213.7 \pm 22.7^{\mathrm{a}}$ & $215.3 \pm 23.7^{\mathrm{a}}$ & $217.7 \pm 17.7^{\mathrm{a}}$ & $215.0 \pm 28.3^{\mathrm{a}}$ \\
\hline & $10-12$ & $215.9 \pm 16.1^{\mathrm{a}}$ & $219.6 \pm 14.1^{\mathrm{a}}$ & $225.0 \pm 17.0^{\mathrm{a}}$ & $219.1 \pm 14.9^{\mathrm{a}}$ \\
\hline & Final & $223.3 \pm 4.0^{\mathrm{a}}$ & $222.8 \pm 2.1^{\mathrm{a}}$ & $233.8 \pm 11.1^{\mathrm{b}}$ & $225.0 \pm 3.8^{\mathrm{a}, \mathrm{b}}$ \\
\hline \multirow[t]{5}{*}{ Total flavanols } & $1-2$ & $417.0 \pm 60.1^{\mathrm{a}}$ & $510.1 \pm 88.2^{\mathrm{b}}$ & $442.8 \pm 67.7^{\mathrm{a}, \mathrm{b}}$ & \\
\hline & $3-5$ & $491.4 \pm 72.1^{\mathrm{a}}$ & $575.8 \pm 86.4^{\mathrm{b}}$ & $520.7 \pm 66.6^{\mathrm{a}, \mathrm{b}}$ & $508.3 \pm 72.0^{\mathrm{a}, \mathrm{b}}$ \\
\hline & $6-9$ & $488.3 \pm 39.9^{a}$ & $554.6 \pm 56.4^{\mathrm{b}}$ & $517.1 \pm 43.4^{\mathrm{a}}$ & $507.8 \pm 44.4^{\mathrm{a}}$ \\
\hline & $10-12$ & $360.7 \pm 44.2^{\mathrm{a}}$ & $410.6 \pm 36.4^{\mathrm{b}}$ & $382.5 \pm 34.0^{\mathrm{a}, \mathrm{b}}$ & $368.6 \pm 43.0^{\mathrm{a}}$ \\
\hline & Final & $321.0 \pm 24.7^{\mathrm{a}}$ & $377.1 \pm 20.2^{b}$ & $346.7 \pm 5.7^{\mathrm{a}}$ & $324.6 \pm 18.0^{\mathrm{a}}$ \\
\hline
\end{tabular}

Different superscripts in the same row indicate significant differences $(\mathrm{p}<0.05)$.

1 In the case of $\mathrm{W}$ wine, the samples were collected as from step 05.

flavan-3-ols are considered ineffective copigments, with the exception of epicatechin in aqueous media since this adopts a nearly planar arrangement for easy stacking with anthocyanins, forming copigmentation complexes (Brouillard, Wigand, Dangles, \& Cheminat, 1991; Liao et al., 1992; Mirabel, Saucier, Guerra, \& Glories, 1999). In addition, since Graciano grapes have a higher content of anthocyanins and flavan3-ols of the epicatechin type than Tempranillo (results not shown) the increased formation of these complexes -pigment-flavanol- during the early stages of winemaking could explain the higher concentration of quantified total pigments reached by the $\mathrm{G}$ wines during this period.

\subsection{Colorimetric characteristics}

Table 3 shows the mean values of the color parameters for all the T, G, M and W wines during alcoholic fermentation (steps 1-2), malolactic fermentation (steps 3-5), aging in oak barrels (steps 6-9) and aging in bottle (steps 10-12). Differences were found among the $T, G, M$ and $W$ wines. In the final stages, when the wines were more stable, $\mathrm{T}$ and $\mathrm{M}$ (37.7 and 37.4 CIELAB units, respectively) showed lower chroma $\left(C^{*}{ }_{a b}\right)$ values than $G(40.7$ CIELAB units, respectively), which means less color vividness. According to this result, higher lightness values $\left(\mathrm{L}^{*}=58.3\right.$ and $\mathrm{L}^{*}=59.2$ CIELAB units) were found in $T$ and $W$ respectively. Higher hue angle $\left(h_{a b}=9.2^{\circ}\right)$ value was found in $T$, this difference was statistically significant $(\mathrm{p}<0.01)$. All these results indicate that the Graciano cv. affords to fairly darker (lower $\mathrm{L}^{*}$ values) and more colorfulness (higher $\mathrm{C}_{\mathrm{ab}}^{*}$ ) wines. $\mathrm{M}$ and W showed differences for $h_{a b}$ in steps 6-12 (stages 3 and 4), with more bluish hues for the $\mathrm{M}$ wines. In the stage 3 , both wines had significantly $(\mathrm{p}<0.01)$ lower $\mathrm{C}^{*}$ ab values ( 45.7 and 45.5 CIELAB units respectively) than $\mathrm{G}$ and were similar to $\mathrm{T}$. These colorimetric results are in agreement with the observed chemical behavior, because although the quantified total pigment concentration in the final stages did not show significant differences among the different wines (Table 3), it was observed that the content in total flavanols (possible copigments) was significantly higher in the $\mathrm{G}$ wine than in the $\mathrm{T}$ and $\mathrm{W}$ wines.

In order to evaluate the colorimetric differences among the wines studied, the color difference values $\left(\Delta \mathrm{E}_{\mathrm{ab}}^{*}\right)$ between the $\mathrm{T}, \mathrm{G}, \mathrm{M}$ and 
Table 4

$\Delta \mathrm{E}^{*}{ }_{\mathrm{ab}}$ between all red wines studied: T, G, M and W, after 12 months of aging in bottle (step 12).

\begin{tabular}{lllll}
\hline$\Delta \mathrm{E}^{*} \mathrm{ab}$ & $\mathrm{T}$ & $\mathrm{G}$ & $\mathrm{M}$ & $\mathrm{W}$ \\
\hline $\mathrm{T}$ & 0.00 & 5.43 & 3.16 & 1.37 \\
$\mathrm{G}$ & 5.43 & 0.00 & 5.19 & 4.18 \\
$\mathrm{M}$ & 3.16 & 5.19 & 0.00 & 2.46 \\
$\mathrm{~W}$ & 1.37 & 4.18 & 2.46 & 0.00 \\
\hline
\end{tabular}

W wines after 12 months of aging in bottle were determined. These were in the 1.37-5.43 CIELAB unit range (Table 4). According to Martínez, Melgosa, Pérez, Hita, and Negueruela (2001), who indicated that $\Delta \mathrm{E}_{\mathrm{ab}}^{*}$ values up to 2.7 CIELAB units represent chromatic changes that can be perceived by the human eye, the $\mathrm{W} / \mathrm{T}$ and $\mathrm{W} / \mathrm{M}$ pairs cannot be clearly detected by a non-trained human eye ( 1.37 and 2.45 , respectively). The $\mathrm{W} / \mathrm{T}$ relation could be due to the fact that co-vinification or coupage (W), led to wines more similar to the monovarietal $\mathrm{T}$ than the co-maceration (M) (3.16 CIELAB units). Furthermore, as shown in Table 3, during the final stages of winemaking, the $\mathrm{W}$ wines had chemical and colorimetric characteristics more similar to the $\mathrm{T}$ wine. That is, the wine present at the highest proportions (Tempranillo) has the greatest effect on the wine obtained from co-vinification (W). Thus, grape blending $(\mathrm{M})$, affords more different wines than wine blending (W).

\subsection{Copigmentation}

The color difference values between the whole and corrected wines $\left(\Delta \mathrm{E}^{*}{ }_{\mathrm{ab}[\mathrm{w}-\mathrm{c}]}\right)$ are shown in Table 5. $\Delta \mathrm{E}_{\mathrm{ab}[\mathrm{w}-\mathrm{c}]}^{\mathrm{w}}$ were in the 5.9-14.9 CIELAB unit range, being around 14 units in the initial stages, in which the copigmentation phenomenon is more marked (Boulton, 2001), and 6 units in the final stages. The high values of the results obtained point to the importance of the copigmentation phenomenon in the color of red wines during the initial stages of winemaking. In addition, in all the tests it was observed that the presence or absence of copigmentation in the same wine produced color changes perceivable by the human eye (Martínez et al., 2001).
In the initial stages (stages 1 and 2) of winemaking, where the copigmentation phenomenon is more important, the $\mathrm{M}$ wines elaborated from blending of grapes (Tempranillo and Graciano), had the highest copigmentation values $\left(\Delta \mathrm{E}_{\mathrm{ab}[\mathrm{w}-\mathrm{c}]}^{*}=14.9\right.$ CIELAB units). According to studies carried out before, the formation of anthocyanins and copigmentation complexes between copigments causes an enhancement of the extraction of anthocyanins during winemaking (Boulton, 2001; Schwarz et al., 2005). This could explain why the M wines initially had a quantified total pigment concentration greater than expected, taking into account that they had only $20 \%$ of G. The same authors indicated that the increase in pigment extraction could be reflected in a more intense red color, together with a bathochromic shift to purplish hues of the red color. These results would be in agreement with the $h_{a b}$ values shown by the $\mathrm{M}$ wines in the final stages of winemaking (steps 10-12), which were significantly lower (bluer) than the $\mathrm{W}$ and $\mathrm{T}$ wines (Table 3). The monovarietal wines elaborated from the Graciano $(G)$ and Tempranillo $(\mathrm{T})$ grape varieties had the lowest copigmentation values $\left(\Delta \mathrm{E}_{\mathrm{ab}[\mathrm{w}-\mathrm{c}]}^{*}=13.4\right.$ CIELAB units and $\Delta \mathrm{E}_{\mathrm{ab}[\mathrm{w}-\mathrm{c}]}^{*}=14.2$ CIELAB units, respectively) (Table 5). The differences among the different wines studied were statistically significant between $\mathrm{M} / \mathrm{G}$. Therefore, the addition of $20 \%$ of the Graciano grape variety to $80 \%$ of Tempranillo grape results in higher of copigmentation values.

The color difference values between final and initial steps $\left(\Delta \mathrm{E}_{\mathrm{ab}[\mathrm{f}-\mathrm{i}]}^{*}\right)$ of each stage were calculated to check the stabilization of the wines (Table 6). In the stage 4 (steps $12-10$ ), the $\mathrm{M}$ and $\mathrm{W}$ wines proved to be the most stable, and the T wine showed a behavior similar to that of $\mathrm{G}$. This latter wine had a higher color difference value during the stages 3 and 4, which was mainly due to changes in quantitative components $\left(\mathrm{L}^{*}\right.$ and $\mathrm{C}_{\mathrm{ab}}^{*}$ ), since in this wine the qualitative component hue $\left(h_{a b}\right)$ was the one showing the least significant change $(p<0.05)$. Thus, co-maceration of the grapes afforded more stable wines than vinification with wine blending, in the stage 4 (aging in bottle stage). More stable wines were obtained when $20 \%$ of the grape variety $G$ was added to the grape variety $\mathrm{T}$, in accordance with higher copigmentation values seen during the initial stages. That is, from the colorimetric standpoint the Graciano variety improved the behavior of the Tempranillo variety, and in this regard it proved to be better to carry out the vinification from the blending of grapes $(\mathrm{M})$ rather than the blend of wines $(\mathrm{W})$, since both the color differences $\left(\Delta \mathrm{E}_{\mathrm{ab}[12-10]}^{*}\right)$ and the differences in the

Table 5

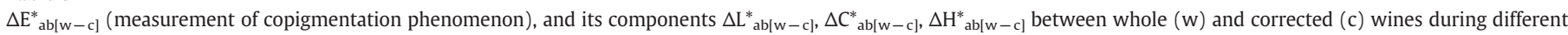
steps (1-2, 3-5, 6-9, 10-12 and final step (step 12)).

\begin{tabular}{|c|c|c|c|c|c|c|}
\hline \multirow[t]{2}{*}{ Stages (Steps) } & & \multicolumn{4}{|l|}{ Wine } & \multirow[t]{2}{*}{ Total } \\
\hline & & [T] & {$[G]$} & {$[\mathrm{M}]$} & {$[\mathrm{W}]^{1}$} & \\
\hline \multirow[t]{4}{*}{$1-2$} & $\Delta \mathrm{E}_{\mathrm{ab}[\mathrm{w}-\mathrm{c}]}$ & $14.2 \pm 1.2^{\mathrm{a}, \mathrm{b}}$ & $13.4 \pm 0.9^{\mathrm{a}}$ & $14.9 \pm 1.2^{\mathrm{b}}$ & - & $14.2 \pm 0.8$ \\
\hline & $\Delta \mathrm{L}_{\mathrm{ab}[\mathrm{w}-\mathrm{c}]}^{*}$ & $-11.7 \pm 1.5^{\mathrm{a}}$ & $-11.8 \pm 1.7^{\mathrm{a}}$ & $-12.7 \pm 1.6^{\mathrm{a}}$ & - & $-12.1 \pm 0.6$ \\
\hline & $\Delta \mathrm{C}^{*}{ }_{\mathrm{ab}[\mathrm{w}-\mathrm{c}]}$ & $6.5 \pm 1.2^{\mathrm{a}, \mathrm{b}}$ & $5.4 \pm 1.6^{\mathrm{a}}$ & $6.8 \pm 1.1^{\mathrm{b}}$ & - & $6.2 \pm 0.7$ \\
\hline & $\Delta \mathrm{H}^{*}{ }_{[\mathrm{w}-\mathrm{c}]}$ & $4.5 \pm 0.6^{\mathrm{b}}$ & $1.8 \pm 1.8^{\mathrm{a}}$ & $3.5 \pm 0.7^{\mathrm{b}}$ & - & $3.3 \pm 1.4$ \\
\hline \multirow[t]{4}{*}{$3-5$} & $\Delta \mathrm{E}_{\mathrm{ab}[\mathrm{w}-\mathrm{c}]}^{*}$ & $12.3 \pm 2.1^{\mathrm{a}}$ & $12.2 \pm 2.0^{\mathrm{a}}$ & $13.7 \pm 2.3^{\mathrm{a}}$ & $11.4 \pm 3.7^{\mathrm{a}}$ & $12.4 \pm 1.0$ \\
\hline & $\Delta \mathrm{L}_{\mathrm{ab}[\mathrm{w}-\mathrm{c}]}^{*}$ & $-9.0 \pm 1.5^{\mathrm{a}}$ & $-10.3 \pm 1.4^{\mathrm{a}}$ & $-10.2 \pm 1.9^{\mathrm{a}}$ & $-8.4 \pm 1.8^{\mathrm{a}}$ & $-9.5 \pm 0.9$ \\
\hline & $\Delta \mathrm{C}_{\mathrm{ab}[\mathrm{w}-\mathrm{c}]}^{*}$ & $5.9 \pm 2.4^{\mathrm{a}}$ & $4.1 \pm 3.0^{\mathrm{a}}$ & $6.7 \pm 2.8^{\mathrm{a}}$ & $5.2 \pm 4.3^{\mathrm{a}}$ & $5.5 \pm 1.1$ \\
\hline & $\Delta \mathrm{H}^{*}{ }_{[\mathrm{w}-\mathrm{c}]}$ & $5.7 \pm 0.6^{b}$ & $4.2 \pm 0.7^{\mathrm{a}}$ & $5.6 \pm 1.7^{b}$ & $5.0 \pm 1.2^{\mathrm{a}, \mathrm{b}}$ & $5.1 \pm 0.7$ \\
\hline \multirow[t]{4}{*}{$6-9$} & $\Delta \mathrm{E}_{\mathrm{ab}[\mathrm{w}-\mathrm{c}]}^{*}$ & $10.3 \pm 1.7^{\mathrm{a}}$ & $10.1 \pm 2.7^{\mathrm{a}}$ & $10.5 \pm 2.9^{\mathrm{a}}$ & $11.1 \pm 5.7^{\mathrm{a}}$ & $10.5 \pm 0.4$ \\
\hline & $\Delta \mathrm{L}^{*}{ }_{\mathrm{ab}[\mathrm{w}-\mathrm{c}]}$ & $-7.4 \pm 1.1^{\mathrm{a}}$ & $-7.8 \pm 1.8^{\mathrm{a}}$ & $-7.4 \pm 2.0^{\mathrm{a}}$ & $-7.9 \pm 4.3^{\mathrm{a}}$ & $-7.6 \pm 0.3$ \\
\hline & $\Delta \mathrm{C}^{*}{ }_{\mathrm{ab}[\mathrm{w}-\mathrm{c}]}$ & $4.4 \pm 2.3^{\mathrm{a}}$ & $4.2 \pm 2.6^{\mathrm{a}}$ & $4.6 \pm 3.1^{\mathrm{a}}$ & $4.7 \pm 5.0^{\mathrm{a}}$ & $4.5 \pm 0.2$ \\
\hline & $\Delta \mathrm{H}^{*}{ }_{[\mathrm{w}-\mathrm{c}]}$ & $5.3 \pm 0.4^{\mathrm{b}}$ & $4.5 \pm 0.9^{a}$ & $5.3 \pm 0.5^{b}$ & $5.2 \pm 0.8^{\mathrm{b}}$ & $5.1 \pm 0.4$ \\
\hline \multirow[t]{4}{*}{$10-12$} & $\Delta \mathrm{E}_{\mathrm{ab}[\mathrm{w}-\mathrm{c}]}$ & $6.7 \pm 1.0^{\mathrm{a}}$ & $6.4 \pm 1.2^{\mathrm{a}}$ & $7.1 \pm 1.0^{\mathrm{a}}$ & $6.5 \pm 1.1^{\mathrm{a}}$ & $6.7 \pm 0.3$ \\
\hline & $\Delta \mathrm{L}_{\mathrm{ab}[\mathrm{w}-\mathrm{c}]}^{*}$ & $-4.4 \pm 0.8^{\mathrm{a}, \mathrm{b}}$ & $-4.6 \pm 1.3^{\mathrm{a}, \mathrm{b}}$ & $-4.7 \pm 0.6^{\mathrm{b}}$ & $-3.6 \pm 1.8^{\mathrm{a}}$ & $-4.3 \pm 0.5$ \\
\hline & $\Delta \mathrm{C}_{\mathrm{ab}[\mathrm{w}-\mathrm{c}]}^{*}$ & $2.3 \pm 1.4^{\mathrm{a}}$ & $1.7 \pm 0.8^{\mathrm{a}}$ & $2.0 \pm 1.7^{\mathrm{a}}$ & $2.1 \pm 1.1^{\mathrm{a}}$ & $2.0 \pm 0.3$ \\
\hline & $\Delta \mathrm{H}^{*}[\mathrm{w}-\mathrm{c}]$ & $4.3 \pm 0.6^{\mathrm{a}}$ & $4.0 \pm 0.9^{\mathrm{a}}$ & $4.6 \pm 0.6^{a}$ & $4.6 \pm 0.6^{a}$ & $4.4 \pm 0.3$ \\
\hline \multirow[t]{4}{*}{ Final } & $\Delta \mathrm{E}_{\mathrm{ab}[\mathrm{w}-\mathrm{c}]}^{*}$ & $5.9 \pm 1.0^{\mathrm{a}}$ & $6.3 \pm 0.8^{a}$ & $6.3 \pm 0.3^{a}$ & $6.5 \pm 0.9^{\mathrm{a}}$ & $6.3 \pm 0.3$ \\
\hline & $\Delta \mathrm{L}_{\mathrm{ab}[\mathrm{w}-\mathrm{c}]}^{*}$ & $-3.8 \pm 0.5^{\mathrm{a}}$ & $-4.2 \pm 1.4^{\mathrm{a}}$ & $-4.0 \pm 0.5^{\mathrm{a}}$ & $-4.1 \pm 0.5^{\mathrm{a}}$ & $-4.0 \pm 0.2$ \\
\hline & $\Delta \mathrm{C}^{*}{ }_{\mathrm{ab}[\mathrm{w}-\mathrm{c}]}$ & $1.7 \pm 1.3^{\mathrm{a}}$ & $2.3 \pm 0.1^{\mathrm{a}}$ & $2.0 \pm 0.3^{a}$ & $2.1 \pm 1.2^{\mathrm{a}}$ & $2.0 \pm 0.3$ \\
\hline & $\Delta \mathrm{H}^{*}{ }_{[\mathrm{w}-\mathrm{c}]}$ & $4.0 \pm 0.4^{\mathrm{a}}$ & $4.0 \pm 0.3^{\mathrm{a}}$ & $4.3 \pm 0.7^{\mathrm{a}}$ & $4.5 \pm 0.7^{\mathrm{a}}$ & $4.2 \pm 0.2$ \\
\hline
\end{tabular}

Data are means \pm standard deviation $(n=3)$. Different superscripts in the same row indicate significant differences $(p<0.05)$.

1 In the case of [W] wine, the samples were collected as from step 05. 
Table 6

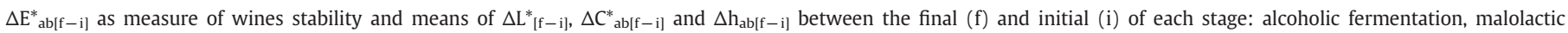
fermentation, aging in oak barrels and aging in bottle.

\begin{tabular}{|c|c|c|c|c|c|}
\hline \multirow[t]{2}{*}{ Stages } & & \multicolumn{4}{|l|}{ Wine } \\
\hline & & $\mathrm{T}$ & G & M & W \\
\hline \multirow{4}{*}{$\begin{array}{l}\text { Alcoholic } \\
\text { fermentation }\end{array}$} & $\Delta \mathrm{E}_{\mathrm{ab}[\mathrm{f}-\mathrm{i}]}$ & $2.9 \pm 0.7^{b}$ & $2.7 \pm 0.6^{b}$ & $1.2 \pm 0.6^{\mathrm{a}}$ & - \\
\hline & $\Delta \mathrm{L}_{[\mathrm{f}-\mathrm{i}]}^{*}$ & $2.3 \pm 0.4^{\mathrm{b}}$ & $0.8 \pm 0.8^{\mathrm{a}}$ & $1.0 \pm 0.6^{\mathrm{a}}$ & - \\
\hline & $\Delta \mathrm{C}^{*}{ }_{\mathrm{ab}[\mathrm{f}-\mathrm{i}]}$ & $-1.3 \pm 0.9^{a}$ & $-0.9 \pm 1.8^{\mathrm{a}}$ & $-0.6 \pm 0.3^{a}$ & - \\
\hline & $\Delta \mathrm{h}_{\mathrm{ab}[\mathrm{f}-\mathrm{i}]}$ & $-0.9 \pm 0.6^{\mathrm{a}}$ & $-0.9 \pm 1.4^{\mathrm{a}}$ & $-0.2 \pm 0.2^{\mathrm{a}}$ & - \\
\hline \multirow{4}{*}{$\begin{array}{l}\text { Malolactic } \\
\text { fermentation }\end{array}$} & $\Delta E^{*}$ ab $[\mathrm{f}-\mathrm{i}]$ & $10.6 \pm 2.5^{a}$ & $8.7 \pm 1.3^{\mathrm{a}}$ & $10.8 \pm 1.4^{\mathrm{a}}$ & - \\
\hline & $\Delta \mathrm{L}_{[\mathrm{f}-\mathrm{i}]}^{*}$ & $2.3 \pm 0.4^{\mathrm{a}}$ & $4.2 \pm 1.0^{\mathrm{a}}$ & $5.5 \pm 0.9^{\mathrm{a}}$ & - \\
\hline & $\Delta \mathrm{C}^{*}{ }_{\mathrm{ab}[\mathrm{f}-\mathrm{i}]}$ & $-1.3 \pm 0.9^{a}$ & $-6.9 \pm 1.6^{\mathrm{a}}$ & $-9.2 \pm 1.3^{\mathrm{a}}$ & - \\
\hline & $\Delta \mathrm{h}_{\mathrm{ab}[\mathrm{f}-\mathrm{i}]}$ & $-0.8 \pm 0.6^{\mathrm{a}}$ & $-2.9 \pm 0.8^{b}$ & $-0.5 \pm 0.7^{\mathrm{a}}$ & - \\
\hline \multirow{4}{*}{$\begin{array}{l}\text { Aging in oak } \\
\text { barrels }\end{array}$} & $\Delta \mathrm{E}_{\mathrm{ab}[\mathrm{f}-\mathrm{i}]}^{*}$ & $6.5 \pm 2.6^{a}$ & $10.0 \pm 2.9^{\mathrm{a}}$ & $10.3 \pm 1.8^{\mathrm{a}}$ & $6.7 \pm 4.7^{\mathrm{a}}$ \\
\hline & $\Delta \mathrm{L}_{[\mathrm{f}-\mathrm{i}]}^{*}$ & $2.0 \pm 2.5^{\mathrm{a}}$ & $6.0 \pm 2.5^{\mathrm{b}}$ & $5.4 \pm 0.6^{\mathrm{a}, \mathrm{b}}$ & $2.5 \pm 3.0^{\mathrm{a}, \mathrm{b}}$ \\
\hline & $\Delta \mathrm{C}^{*}{ }_{\mathrm{ab}[\mathrm{f}-\mathrm{i}]}$ & $-4.0 \pm 4.0^{\mathrm{a}}$ & $-7.7 \pm 1.9^{a}$ & $-8.3 \pm 2.6^{\mathrm{a}}$ & $-4.6 \pm 5.4^{\mathrm{a}}$ \\
\hline & $\Delta \mathrm{h}_{\mathrm{ab}[\mathrm{f}-\mathrm{i}]}$ & $3.4 \pm 2.4^{\mathrm{b}}$ & $-0.2 \pm 2.2^{\mathrm{a}}$ & $2.1 \pm 2.1^{\mathrm{a}, \mathrm{b}}$ & $2.3 \pm 1.1^{\mathrm{a}, \mathrm{b}}$ \\
\hline \multirow[t]{4}{*}{ Aging in bottle } & $\Delta \mathrm{E}_{\mathrm{ab}[\mathrm{f}-\mathrm{i}]}^{*}$ & $7.7 \pm 3.3^{\mathrm{a}}$ & $7.5 \pm 3.8^{\mathrm{a}}$ & $5.8 \pm 0.9^{a}$ & $6.7 \pm 2.9^{a}$ \\
\hline & $\Delta \mathrm{L}_{[\mathrm{f}-\mathrm{i}]}^{*}$ & $3.3 \pm 2.5^{\mathrm{a}}$ & $4.2 \pm 3.0^{\mathrm{a}}$ & $2.5 \pm 0.6^{\mathrm{a}}$ & $3.3 \pm 2.5^{\mathrm{a}}$ \\
\hline & $\Delta \mathrm{C}^{*}{ }_{\mathrm{ab}[\mathrm{f}-\mathrm{i}]}$ & $-5.7 \pm 3.0^{\mathrm{a}}$ & $-5.4 \pm 3.0^{\mathrm{a}}$ & $-4.1 \pm 1.4^{\mathrm{a}}$ & $-4.5 \pm 2.9^{\mathrm{a}}$ \\
\hline & $\Delta \mathrm{h}_{\mathrm{ab}[\mathrm{f}-\mathrm{i}]}$ & $5.0 \pm 0.3^{c}$ & $3.4 \pm 0.1^{\mathrm{a}}$ & $4.5 \pm 0.7^{\mathrm{b}, \mathrm{c}}$ & $4.1 \pm 0.4^{\mathrm{b}}$ \\
\hline
\end{tabular}

Data are means \pm standard deviation $(n=3)$. Different superscripts in the same row indicate significant differences $(p<0.05)$.

quantitative (lightness and chroma) and qualitative (hue) components were lower and more favourable in the $M$ than in the $\mathrm{W}$ wine. $\mathrm{G}$ and $\mathrm{T}$ were the wines those showed the less stable color $\left(\Delta \mathrm{E}_{\mathrm{ab}[12-10]}^{*}=7.5\right.$ and 7.7 CIELAB units, respectively), in accordance with lower copigmentation values seen during the initial stages $\left(\Delta \mathrm{E}_{\mathrm{ab}[\mathrm{w}-\mathrm{c}]}^{*}=13.4\right.$ and 14.2 CIELAB units respectively (Table 5)). $G$ had the lowest copigmentation values during the initial stage $\left(\Delta \mathrm{E}_{\mathrm{ab}[\mathrm{w}-\mathrm{c}]}^{*}=13.4\right.$ CIELAB units (Table 5)) and high color difference values were obtained in the final stages 3 and $4\left(\Delta \mathrm{E}_{\mathrm{ab}[9-6]}^{*}=10.0\right.$ and $\Delta \mathrm{E}_{\mathrm{ab}[12-10]}^{*}=7.5$ CIELAB units respectively (Table 6)). Therefore, it may be stated that copigmentation positively influences the later stability of wines (Boulton, 2001; Darías-Martín et al., 2002; Hermosín-Gutiérrez, Sánchez-Palomo, \& Vicario-Espinosa, 2005). Thus, with regard to the stability of the final wine, the blending of wines affords wines that are not very stable and are similar to $\mathrm{G}$ wines, and the blending of grapes leads to more stable wines.

Accordingly, studies of the qualitative and quantitative components of the color differences between whole wines (with copigmentation) and corrected wines (without copigmentation) were carried out. The $\left(a^{*} b^{*}\right)$ color diagrams of the whole and corrected wine samples are shown in Fig. 2. The distribution of the samples is different as a function of whether the copigmentation phenomenon is present or not. The samples of whole wines are localized in the $\left(-1^{\circ}\right)$ to $10^{\circ}$ zone of the $\left(a^{*} b^{*}\right)$ diagram and show chroma values $\left(C^{*}{ }_{a b}\right)$ of 34-63 CIELAB units. The color of the wines with co-pigmentation (whole wines) displayed high chromatic intensity and a clearly violet hue. However, when the effect of co-pigmentation was removed from these wines and the dilution factor was applied in the calculation of the new chromatic parameters higher hue values (between $4^{\circ}$ and $17^{\circ}$ ) and lower chroma values (30-59 CIELAB units) than the original ones were obtained, which accounts for the displacement of the samples towards the zone of more reddish hues in the $\left(\mathrm{a}^{*} \mathrm{~b}^{*}\right)$ diagram. According to the distribution of the $\left(a^{*} b^{*}\right)$ samples, it may be seen that the "reconstructed" color of the wines - i.e., those from which the effect of copigmentation was removed - had lower chromatic intensity and a loss of blue hues with respect to the color expected theoretically from the Lambert-Beer Law. These results show that an important part of the expression of the color of the anthocyanins is due the copigmentation phenomenon in which they are involved, which leads to changes at both qualitative and quantitative levels in the color of the wine, specifically favoring higher chromatic intensities and bluish hues. A two-level repeated measures MANOVA was applied to check whether the differences observed in the $a^{*} b^{*}$ diagram were significant $(p<0.01)$ for both coordinates, $\mathrm{a}^{*}$ and $\mathrm{b}^{*}$, for the four wines studied (T, G, M and $\mathrm{W}$ ) in the initial and final stages. This indicated that the copigmentation phenomenon significantly affected $(p<0.05)$ the color of all the wines, regardless of whether they were elaborated from different varieties (Tempranillo, Graciano and blends thereof) or whether they were elaborated differently (co-maceration and co-vinification).

When the parameter evaluated was $\Delta \mathrm{E}_{\mathrm{ab}[\mathrm{w}-\mathrm{c}]}^{*}$ in the initial stages (Table 5), the differences found between $\mathrm{T}$ and $\mathrm{G}$ were not significant. Accordingly, it is clear that it is necessary to study the co-pigmentation phenomenon not only globally but also by a study of the qualitative and quantitative components of the color. In this sense, Table 5 shows the values of the $\Delta \mathrm{L}_{\mathrm{ab}[\mathrm{w}-\mathrm{c}]}^{*} \Delta \mathrm{C}_{\mathrm{ab}[\mathrm{w}-\mathrm{c}]}$ and $\Delta \mathrm{H}^{*}{ }_{[\mathrm{w}-\mathrm{c}]}$, colorimetric parameters of the whole and corrected wines and their differences for each type of wine. Following application of the two-level repeated measures MANOVA test for the colorimetric variables between the whole and corrected wines significant differences $(p<0.01)$ were consistently obtained in the four wines studied, (T, G, M and W), in the initial and final stages. Table 5 shows that the difference in chroma and hue in the initial stages (steps $1-2)$ is significantly smaller $(\mathrm{p}<0.05)$ for wine $\mathrm{G}\left(\Delta \mathrm{C}_{\mathrm{ab}[\mathrm{w}-\mathrm{c}]}^{*}=5.4\right.$ and $\left.\Delta \mathrm{H}^{*}{ }_{[\mathrm{w}-\mathrm{c}]}=1.8\right)$ as compared with [T] $\left(\Delta \mathrm{C}^{*}{ }_{\mathrm{ab}[\mathrm{w}-\mathrm{c}]}=6.5\right.$ y $\left.\Delta \mathrm{H}^{*}{ }_{[\mathrm{w}-\mathrm{c}]}=4.5\right)$ and $\mathrm{M} \quad\left(\Delta \mathrm{C}^{*}{ }_{\mathrm{ab}[\mathrm{w}-\mathrm{c}]}=6.8 \mathrm{y}\right.$ $\left.\Delta \mathrm{H}^{*}{ }_{[\mathrm{w}-\mathrm{c}]}=3.5\right)$.

\section{Conclusions}

In summary, regardless of vintage, the Graciano cv. affords to fairly darker and more colorfulness wines, and $\mathrm{M}$ wines more bluish hues than $\mathrm{W}$. Also, the color difference values $\left(\Delta \mathrm{E}^{*} \mathrm{ab}\right)$ indicated that the wine present at highest proportions $(\mathrm{T})$ has the greatest effect on the wine obtained from co-vinification (W). Regarding the copigmentation values, the high values of the results obtained point to the importance of this phenomenon in the color of red wines during the initial stages of winemaking; being the wines elaborated from blending of grapes (M) those with the highest values. Finally, the interpretation of the components of $\Delta \mathrm{E}_{\mathrm{ab}}^{*}$ - lightness, chroma, and especially hue differences, as the expression of qualitative observable change is very important. Therefore, tristimulus colorimetry is a good alternative in the comprehensive evaluation of the effect of the copigmentation on the wine; since in addition to confirming the importance of this process in the early stages of winemaking, through the use of the full spectrum, quantitative data are obtained that allow a visual interpretation of the changes involved. 
a $\left(a^{*} b^{*}\right)$ Diagram

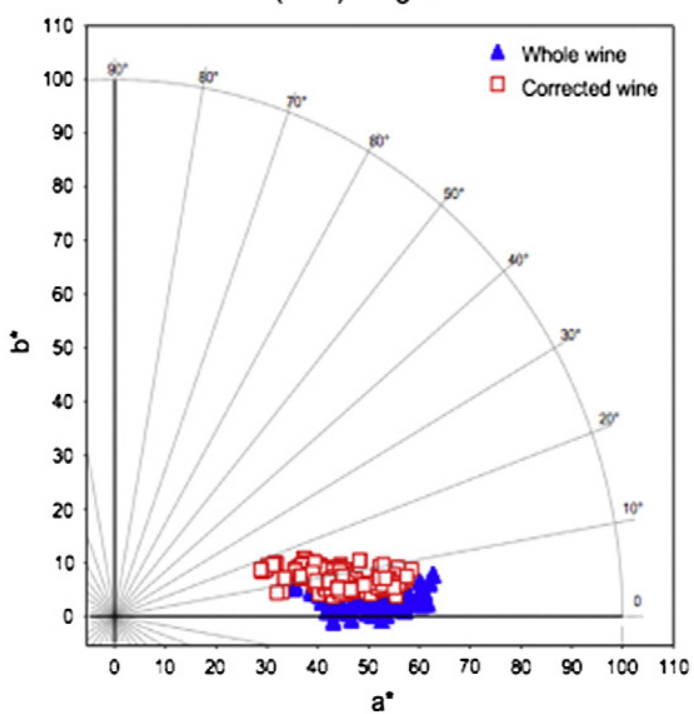

b

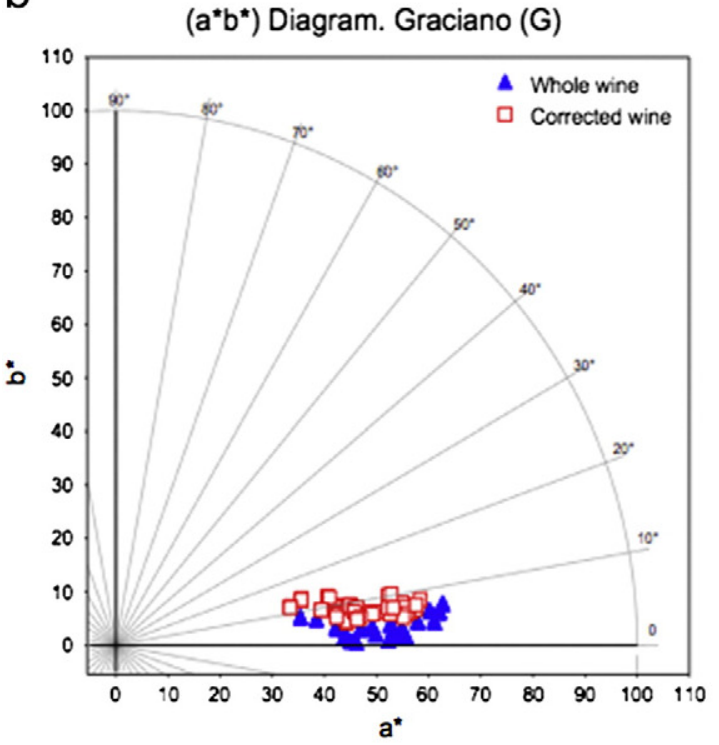

d

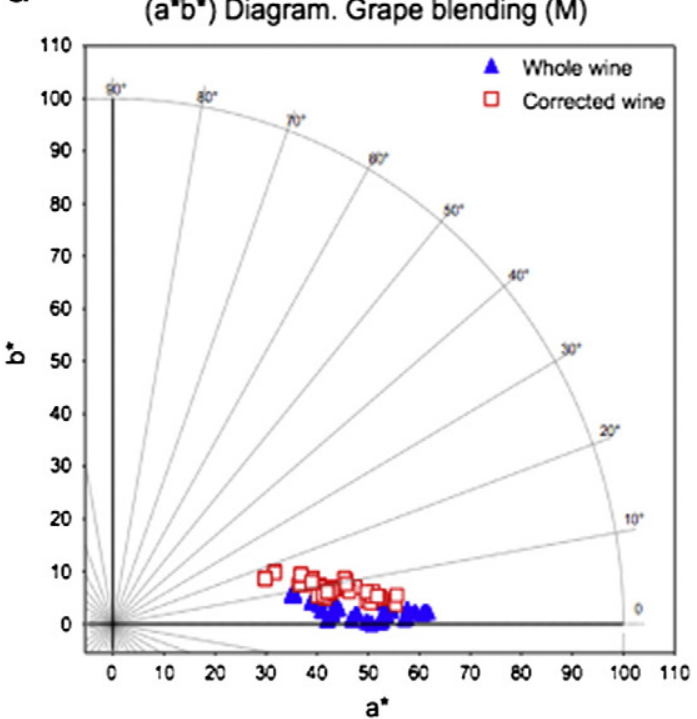

C

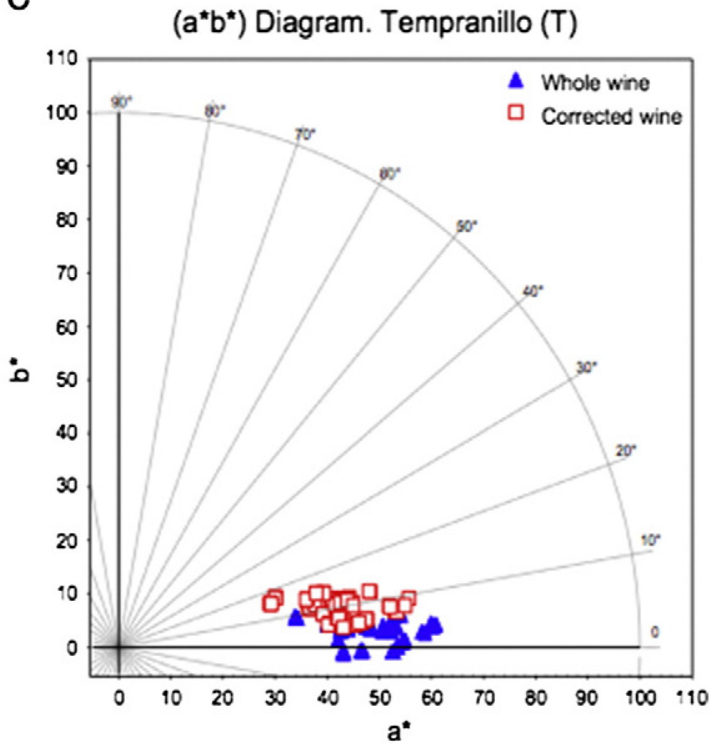

e

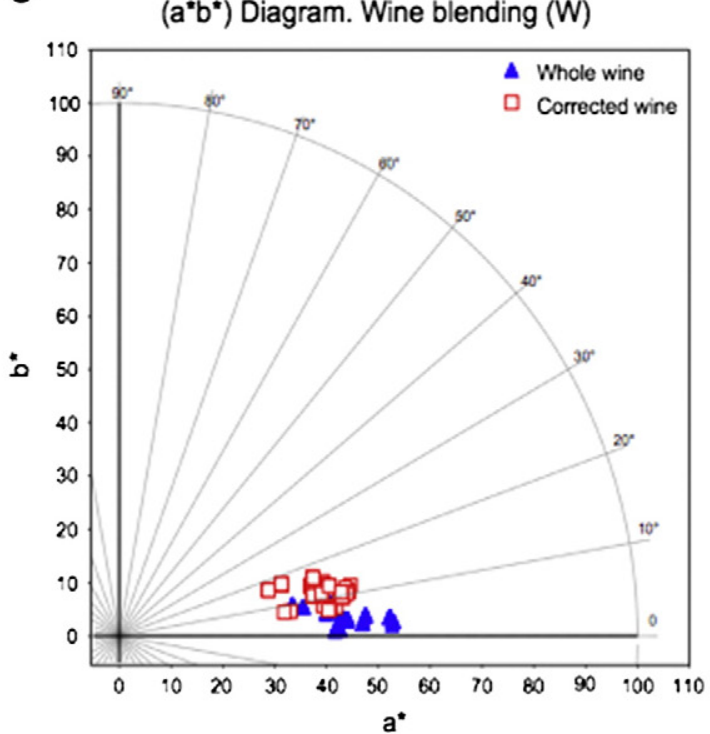

Fig. 2. (a* $b^{*}$ ) Color diagram of the whole and corrected wines: (a) all wines; (b) G wines; (c) T wines; (d) M wines; (e) W wines. 


\section{Acknowledgments}

Thanks are due to Spanish CICYT (AGL2005-07245-C03) and Bodegas Roda S.A. for supplying the wine samples.

\section{References}

Boulton, R. B. (1996). A method for the assessment of copigmentation in red wines. The 47th annual meeting of the American Society for Enology and Viticulture, Reno, Nevada (EEUU) (Cited in American Journal of Enology and Viticulture, 47, 346).

Boulton, R. B. (2001). The copigmentation of anthocyanins and its role in the color of red wine. A critical review. American Journal of Enology and Viticulture, 52, 67-87.

Brouillard, R., Mazza, G., Saad, Z., Albrecht-Gary, A. M., \& Cheminat, A. (1989). The copigmentation reaction of anthocyanins: A microprobe for the structural study of aqueous solutions. Journal of the American Chemical Society, 111, 2604-2610.

Brouillard, R., Wigand, M. C., Dangles, O., \& Cheminat, A. (1991). The pH and solvent effects on the copigmentation reaction of malvin with polyphenols, purine and pyrimidine derivatives. Journal of the Chemical Society-Perkin Transactions II, 2, 1235-1241.

Cavalcanti, R. N., Santos, D. T., \& Meireles, M. A. A. (2011). Non-thermal stabilization mechanisms of anthocyanins in model and food systems - An overview. Food Research International, 44, 499-509.

CIE (2004). Colorimetry. Publications CIE. Commission Internationale de l'Eclairage Central Bureau, Technical Report. Viena (Austria): CIE (15.2).

Darías-Martín, J. Carrillo, M. Díaz, E. \& Boulton, R. B. (2001). Enhancement of red wine colour by pre-fermentative addition of copigments. Food Chemistry, 73, 217-220.

Darías-Martín, J., Martín-Luis, B., Carrillo-López, M., Lamuela-Raventós, R., Díaz-Romero C., \& Boulton, R. (2002). Effect of caffeic acid on the color of red wine. Journal of Agricultural and Food Chemistry, 50, 2062-2067.

Escribano-Bailón, M. T., Gutiérrez-Fernández, Y., Rivas-Gonzalo, J. C., \& Santos-Buelga, C. (1992). Characterization of procyanidins of Vitis vinifera variety Tinta del País grape seeds. Journal of Agricultural and Food Chemistry, 40, 1794-1799.

Escudero-Gilete, M. L., González-Miret, M. L., \& Heredia, F. J. (2010). Implications of blending wines on the relationships between the colour and the anthocyanic composition. Food Research International, 43, 745-752.

García-Barceló, J. (1980). Técnicas Analíticas para vinos. Barcelona: GAP.

García-Marino, M., Hernández-Hierro, J. M., Rivas-Gonzalo, J. C., \& Escribano-Bailón, M. T. (2010). Colour and pigment composition of red wines obtained from co-maceration of Tempranillo and Graciano varieties. Analytica Chimica Acta, 660, 134-142.

García-Marino, M., Ibañez, E., Rivas-Gonzalo, J. C., \& García-Moreno, C. (2006). Recovery of catechins and proanthocyanins from winery by-products using subcritical water extraction. Analytica Chimica Acta, 563, 44-50.

García-Marino, M., Santos-Buelga, C., Rivas-Gonzalo, J. C., \& Escribano-Bailón, M. T. (2009). Las prácticas enológicas en la evolución del contenido fenólico. La Semana Vitivinícola, 3248, 6-14.

Glories, Y. (1984). La coleur des vins rouges. $2^{\text {eme }}$ partier. Mesure, origine et interpretation. Connaissance de la Vigne et du Vin, 18. (pp. 253-271).

Gómez-Míguez, M., González-Manzano, S., Escribano-Bailón, M. T., Heredia, F. J., \& Santos-Buelga, C. (2006). Influence of different phenolic copigments on the color of malvidin 3-glucoside. Journal of Agricultural and Food Chemistry, 54, 5422-5429.

Gonzalez-Manzano, S., Dueñas, M., Rivas-Gonzalo, J. C., Escribano-Bailón, M. T., \& Santos-Buelga, C. (2009). Studies on the copigmentation between anthocyanins and flavan-3-ols and their influence in the colour expression of red wine. Food Chemistry, 114, 649-656.

González-Manzano, S., Santos-Buelga, C., Dueñas-Patón, M., Rivas-Gonzalo, J. C., \& Escribano, M. T. (2008). Colour implications of self-association processes of wine anthocyanins. European Food Research and Technology, 226, 483-490.

Heredia, F. J., Álvarez, C., González-Miret, M. L., \& Ramirez, A. (2004). CromaLab®, análisis de color. Registro General de la Propiedad Intelectual SE-1052-04 (Sevilla (Spain)).
Hermosín-Gutiérrez, I., Sánchez-Palomo, E., \& Vicario-Espinosa, A. (2005). Phenolic composition and magnitude of copigmentation in young and shortly aged red wines made from the cultivars, Cabernet Sauvignon, Cencibel, and Syrah. Food Chemistry, 92, 269-283.

Liao, H., Cai, Y., \& Haslam, E. (1992). Polyphenol interactions. Anthocyanins: Copigmentation and colour changes in red wines. Journal of the Science of Food and Agriculture, 59, 299-305.

Liu, H., Chen, Y., Hao, Y., Zheng, N., \& Jia, A. (2012). The evaluation of lightness and chroma difference for images according to color difference formulae. Applied Mechanics and Materials, 130, 3036-3040.

Martínez, J. A., Melgosa, M., Pérez, M. M., Hita, E., \& Negueruela, A. I. (2001). Visual and instrumental colour evaluation in red wines. Food Science and Technology Internacional, 7, 439-444.

Melgosa, M., Gómez-Robledo, L., Huertas, R., Capitán-Vallvey, L. F., Moyano, M. J., \& Heredia, F. J. (2009). Color measurements in blue-tinted cups for virgin-olive-oil tasting. Journal of the American Oil Chemists' Society, 86, 627-636.

Mirabel, M., Saucier, C., Guerra, C., \& Glories, Y. (1999). Copigmentation in model wine solutions: occurrence and relation to wine aging. American Journal of Enology and Viticulture, 50, 211-218.

Monagas, M., Bartolomé, B., \& Gómez-Cordovés, C. (2006). Effect of the modifier (Graciano vs. Cabernet Sauvignon) on blends of Tempranillo wine during ageing in the bottle. I. Anthocyanins, pyranoanthocyanins and non-anthocyanin phenolics. LWT- Food Science and Technology, 39, 1133-1142.

Monagas, M., Gómez-Cordovés, C., Bartolomé, B., Laureano, O., \& Ricardo Da Silva, J. M. (2003). Monomeric, oligomeric and polymeric flavan-3-ol composition of wines and grapes from Vitis vinifera L. cv. Graciano, Tempranillo and Cabernet Sauvignon. Journal of Agricultural and Food Chemistry, 51, 6475-6481.

Moreno-Arribas, M. V., \& Polo, C. (2008). Wine chemistry and biochemistry. New York: Springer.

Norman, G. R., \& Streiner, D. L. (1996). Bioestadística. Madrid: Mosby/Doyma Libros S.A., Times Mirror International Publishers.

Núñez, V., Gómez-Cordovés, C., Bartolomé, B., Hong, Y. J., \& Alysone-Mitchell, A. E. (2006). Non-galloylated and galloylated proanthocyanidin oligomers in grape seeds from Vitis vinifera L. cv. Graciano, Tempranillo and Cabernet Sauvignon. Journal of the Science of Food and Agriculture, 86, 915-921.

OIV (2009). Récuil des méthodes internationales d'analyse des vins et des moûts. Paris, France: Office International de la Vigne et du Vin.

Oleari, C., Melgosa, M., \& Huertas, R. (2011). Generalization of color difference formulas for any illuminant and any observer by assuming perfect color constancy in a color-vision model based on the OSA-UCS system. Journal of the Optical Society of America. A, Optics, Image Science, and Vision, 28(11), 2226-2234.

Ribéreau-Gayon, P., \& Stonestreet, E. (1965). Determination of anthocyanins in red wine. Bulletin de la Societe Chimique de France, 9, 2649-2652.

Rodríguez-Pulido, F. J., Gómez-Robledo, L., Melgosa, M., Gordillo, B., González-Miret, M. L., \& Heredia, F. J. (2012). Ripeness estimation of grape berries and seeds by image analysis. Computers and Electronics in Agriculture, 82, 128-133.

Schwarz, M., Picazo-Bacete, J. J., Winterhanlter, P., \& Hermosín-Gutiérrez, I. (2005). Effect of copigments and grape cultivar on the color of red wines fermented after the addition of copigments. Journal of Agricultural and Food Chemistry, 53, 8372-8381.

Somers, T. C. \& Evans, M. E. (1977). Spectral evaluation of young red wines: Anthocyanin equilibria, total phenolic, free and molecular $\mathrm{SO}_{2}$, "chemical age". Journal of Agricultural and Food Chemistry, 28, 279-287.

StatSoft (2007). Statistica 8.0 (data analysis software system). Tulsa, OK: StatSoft Inc. (Available at, http://www.statsoft.com)

Zheng, Y., Zhou, S., Qi, Y., \& Zhang, L. (2012). Performance of CIE LAB-based color difference formulae under different viewing conditions. Advanced Materials Research, 457, 1294-1298. 